Original Paper http://ajol.info/index.php/ijbcs http://indexmedicus.afro.who.int

\title{
Determinants of crop-livestock integration by small farmers in Benin
}

\section{B. Ivan KOURA ${ }^{1 *}$, Houinsou DEDEHOUANOU ${ }^{2}$, H. Luc DOSSA $^{1}$, B. Vital KPANOU ${ }^{2}$, Frédéric HOUNDONOUGBO ${ }^{1}$, Pascal HOUNGNANDAN ${ }^{3}$, G. Apollinaire MENSAH ${ }^{4}$ et Marcel HOUINATO ${ }^{1}$}

${ }^{I}$ Department of Animal Sciences, Faculty of Agricultural Sciences, University of Abomey-Calavi, 01 BP 526 Cotonou, Benin.

${ }^{2}$ Department of Economy, Socio-Anthropology and Communication, Faculty of Agricultural Sciences, University of Abomey-Calavi, 01 BP 526 Cotonou, Benin.

${ }^{3}$ Department of Crop Sciences, Faculty of Agricultural Sciences, University of Abomey-Calavi, 01 BP 526 Cotonou, Benin.

${ }^{4}$ Agricultural National Research Institute of Benin, 06 BP 629 Cotonou, Benin.

*Corresponding author; E-mail: kouraivan@gmail.com;(01 BP 526 Cotonou; Tel: (+229) 97019780/64321378Koura BI.)

\section{ACKNOWLEDGEMENTS}

The authors are grateful to the University of Abomey-Calavi for funding the present work through the project "Productivity of integrated Crop-livestock systems in Benin" (PROSAEI/PFCR2/UAC).

\begin{abstract}
Despite the numerous work conducted on integrated crop-livestock systems, very little is known about factors determining farmers' trend to integrate. Our study aimed at a socioeconomic characterization of endogenous crop-livestock integration in Benin and identification of determinants of farmers' decision to use these practices. Two hundred and forty farmers were surveyed in three agro-ecological regions randomly selected. A semi-structured questionnaire was used to collect information on farmer's characteristics, production factors and agriculture and breeding by-products valorization practices. On the basis of main links between both productions, three integration levels (no integration, NI: 36\%; partial integration, PI: 55\%; total integration, TI: 9\%) were identified and characterized according to socioeconomic characteristics of farmers. Then the multinomial logistic regression technique was used to predict the integration level of a given farmer in function of its socioeconomic characteristics. The three integration levels differ significantly $(\mathrm{p}<0.001)$ according to variables such as membership in farmers' association, educational level, weight of agricultural experience, farming equipment and size of herds. The decision by a farmer to choose the total integration type significantly depends $(\mathrm{p}<0.001)$ on the size of his cattle herd, his membership in farmers' association, the weight of his agricultural experience and his equipment value. Thus, integration is a practice used by small farmers with good experience in agriculture. Strategies for improving integration of cropping and breeding are to motivated farmers for cattle keeping and membership in an association.

(C) 2015 International Formulae Group. All rights reserved.
\end{abstract}

Keywords: Animal feeding, integrated soil fertility management, resilience, sustainability. 


\section{INTRODUCTION}

Crop and livestock productions employ in sub-Saharan Africa more than $60 \%$ of the workforce (FAO, 2009). Declining soil fertility (Dercon, 2002; Vall et al., 2012), feed scarcity (Coulibaly, 2008; Vall et al., 2012; Koura et al., 2015) and reduction of space (Vall et al., 2006, 2012; Koura et al., 2015) threat the two productions (Dercon, 2002; Coulibaly, 2008; Koura et al., 2015) which can no more satisfy food availability. Integration of crop farming and livestock rearing is well known in West-Africa to improve the resilience of small farmers to ongoing risks (Franke et al., 2008; Vall et al., 2012). Integrated crop-livestock systems (ICLS) are considered as improved practices for production intensification with ecological benefits on environment (Dugue and Dongmo, 2004; Rufino, 2008; Vall et al., 2012). But, many farmers in sub-Saharan Africa fail to integrate the two productions. Very few of them have adopted these practices despite its promotion by agricultural extension services (Dugue and Dongmo, 2004). Reason of no adoption has often led to difficulties in technical management strategy of the farm (Thornton and Herrero, 2001). Adoption of farming practices is acknowledged to be influenced by farms' socioeconomic characteristics (Adesina and Chianu, 2002; Somda et al., 2002; Nkamleu and Manyong, 2005). In the case of ICLS, while many research insights focused on the integrated crop-livestock practices per se and their importance (Thornton and Herrero, 2001; Dugue and Dongmo, 2004; Rufino, 2008; Franke, 2010; Vall et al., 2012), little is known about the socio-economic factors affecting small farmers' decision to adopt them. The present study aims at identifying and understanding socio-economic factors of farms which influence adoption of integrated crop-livestock systems. This could help improving strategies for increasing adoption rates of these practices.

\section{MATERIALS AND METHODS \\ Conceptual framework}

Integrated crop-livestock systems (ICLS) are based on the premise that byproducts from the two original systems are used on the same farm, and draught power, use of roughages and low quality feeds, closed nutrient cycling through the soil, plants and the animals' manure, and improved soil fertility contribute to overall higher outputs per animal and per hectare (Mohammed Saleem, 1997). Complexity of ICLS in subSaharan and difficulties to apprehend their components limit their description (Thornton and Herrero, 2001). Existing characterization models emphasize on the description of components and their interaction. Analysis of links between components remains the most used for those systems' descriptions (Smith et al., 1997; Wolmer, 1997). According to Wolmer (1997), integration link is made through manure's utilization for fertilization, crop residues' feeding, other fodder sources like growing forage crops, leguminous trees, agro-industrial by-products and animal traction. As our study focused on farmers from different areas, so were they heterogeneous of both agricultural and breeding practices, the highlighted links were chosen for the description of integration. Draught power is spread in cattle breeding and cotton production areas (Vallet al., 2006) while agro-industrial by-products uses remain high in periurban areas and forage cultivation practices are rare in general (Wolmer, 1997). Integrated crop-livestock systems (ICLS) are therefore mainly reduced here to "manure for fertilization" and "crop residues (cereals hay, leaves and pods from legumes, leaves from roots/tubers) for feeding" practices as explained by Franke et al. (2008).

\section{Study area}

The study was conducted in three agroecological regions of Benin, randomly selected out the eight existing. These are the 
food crop area in southern Borgou region (region III) in the north, the bar land area (region VI) and the fishery area (region VIII) in the south of the country.

Located between $9.4^{\circ}$ and $10.6^{\circ}$ of latitude North and between $2^{\circ}$ and $3.2^{\circ}$ of longitude East, Region III is of sudanian type with one rainy season of 900-1300 mm/year. Vegetation is dominated by shrubby and three savannah (Akoegninou et al., 2006). Soil is of tropical ferralitic type (Volkoff, 1976). Agricultural production focused on food crops like yams, cereals, peanuts and industrial crops like soybean and cotton. Poultry, cattle, small ruminants, pigs and horses are the mostly kept farm animals (INSAE, 2012). .

Region VIis between $6.4^{\circ}$ and $6.9^{\circ}$ of latitude North and between $2^{\circ}$ and $2.4^{\circ}$ of longitude East. This region is characterized by a Soudano-guinean climate type with two rainy seasons and about 800 to $1.400 \mathrm{~mm}$ of rain per year. The vegetation is constituted of grass savanna; grassland, semi deciduous and relic forest (Akoegninou et al., 2006). Ferralitic soil and hydromorphic soil types (Volkoff, 1976) predominate. Maize, cassava, peanuts, pineapple (industrial crop) and oil palm trees are produced and poultry, small ruminant and pigs are bred (INSAE, 2012).

Region VIII is a sub-equatorial area with two rainy seasons and 1000 to $1400 \mathrm{~mm}$ of rain distributed on 100 days. Vegetation is mainly grass savanna, grassland and marshy grass (Akoegninou et al., 2006). Soils are hydromorphic and sandy (Volkoff, 1976). Farmers are involved in vegetable gardening, cropping maize, peanuts and cassava, and rearing of poultry, small ruminants, rabbit and pig(INSAE, 2012).This region is located between $6.3^{\circ}$ and $7.2^{\circ}$ of latitude North and between $2.4^{\circ}$ and $2.7^{\circ}$ of longitude East.

\section{Data collection}

Between July and October 2013, a total of 240 indigenous/autochthon farmers were surveyed in the three agro-ecological zones. Two communes were randomly selected in each agro-ecological and snowball sampling procedure (Babbie, 2009) was used to randomly select and interview 40 farmers per commune. The questionnaire used encompassed information on farmers' socioeconomic characteristics, including their resources endowment; their uses of crop residues and manure. All the variables included in the questionnaire are defined in Table 1.

\section{Statistical analysis}

All Statistical analysis was performed in SPSS / PASW 17 (SPSS Inc., 2010).

\section{Integration characteristics}

On the basis of "manure for fertilization" and "crop residues for feeding", practices use, three levels of integration were identified: (1) No integration (NI: utilization of neither crop residues nor manure), (2) partial integration (PI: utilization of either manure as fertilizer or crop residues for feeding purposes) and (3) total integration (TI: utilization of both manure and crop residues).The socioeconomic characteristics of the surveyed farmers were compared across the three groups of integration. Crosstabulations, with calculation of chi-square $\left(\chi^{2}\right)$ statistics were used to compare the qualitative characteristics whereas means and standard deviations of the numerical variables were calculated and compared across the three groups using the non-parametric KruskalWallis W test.

\section{Determinants of crop livestock integration}

Characteristics of farmers that showed statistically significant differences $(p<0.001)$ across groups in the bivariate analyses were retained in the Multinomial Logistic 
Regression Analysis using the backward procedure to identify factors that affect farmers' choice of a certain level of integration (1: no integration, 2: partial integration or 3: total integration). Correlations between selected variables were analyzed by calculating Pearson coefficient and allowed to reduce the number of predictors. In fact, when two variables are highly correlated, only one is retained in the predictors list. Decision is taken according to the relevance of each of the two variables to predict integration.

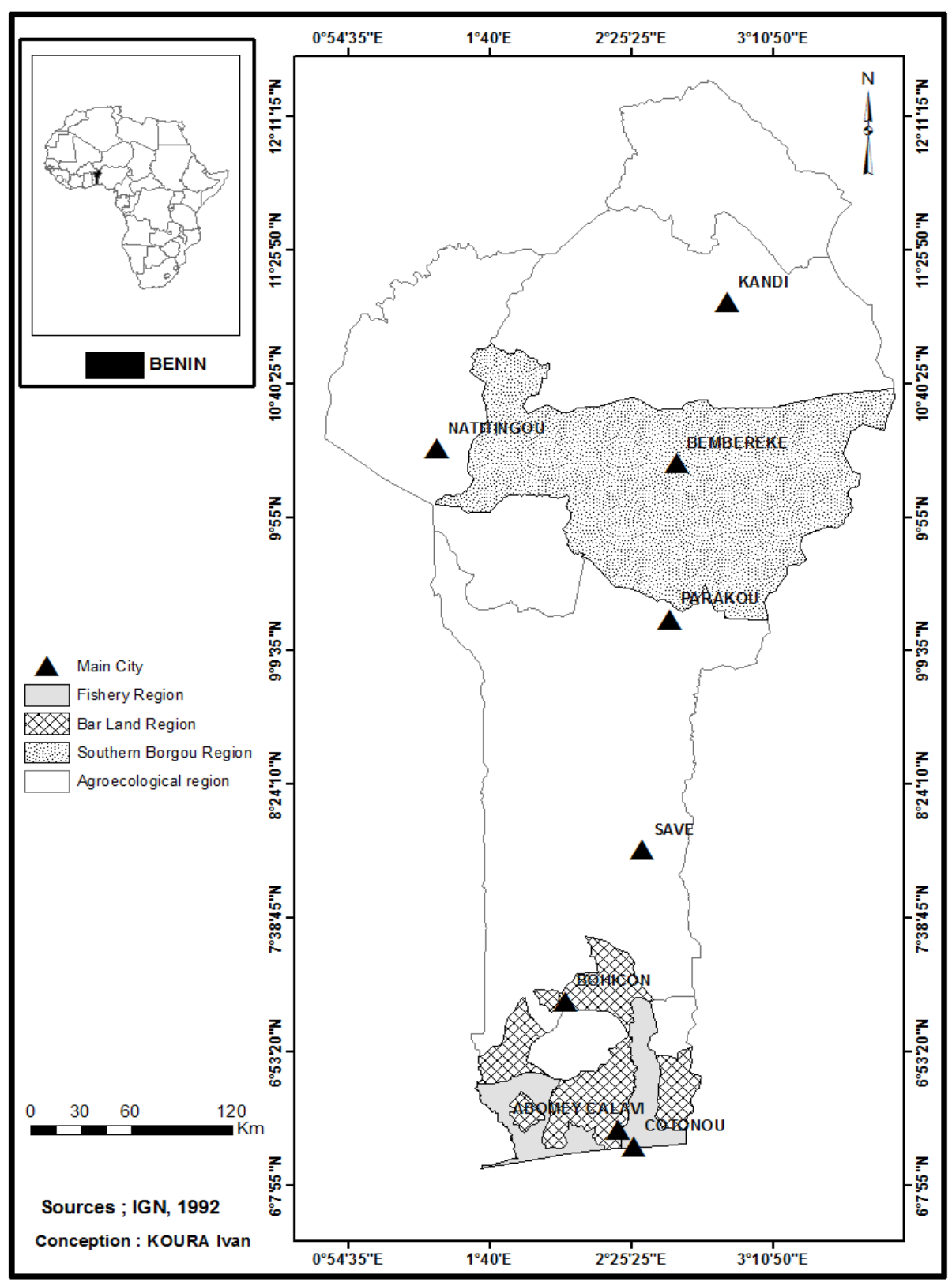

Figure 1: Map of the study area showing the three agroecological areas surveyed. 


\section{RESULTS}

Socioeconomic characteristics of farmers

Only $32 \%$ of the 240 surveyed farmers

used crops residues for animal feeding and $41 \%$ manure to fertilize their crop/garden fields. These results suggest that partial integration type is most commonly practiced. Tables 2 and 3 present the socioeconomic characteristics of the farmers across the three types of integration.

A significantly $(\mathrm{p} \leq 0.001)$ higher proportion of rural than urban and periurban farmers were practicing TI. Also, almost half of the farmers who practiced no integration (NI) had no formal education. Farmers who practiced no integration had the lowest ( $\mathrm{p}$ $<0.001)$ number of small ruminants per herd (5.24 heads) and cattle herd size (1.61 heads). Their poultry flock size (23) is also significantly low but higher than that of farmers which practiced partial integration. They were also characterized by the lowest ( $\mathrm{p}$ $<0.001)$ equipment value (355063 FCFA), were the least educated $(\mathrm{p}<0.01)$ and were more present in periurban (71\%) than in rural areas $(29 \%)$. The group of farmers involved in partial integration (PI) had the least $(\mathrm{p}<0.01)$ experience in crop/garden farming (16 years in average) but relatively high cultivated land sizes (about 7 ha). This group was more present in urban $(55 \%)$ than in rural $(32 \%)$ areas but shared similarities with the group of farmers practicing in terms of livestock herd sizes. Farmers practicing total integration (TI) had the longest $(\mathrm{p}<0.01)$ experience in crop cultivation (22 years in average), the largest cultivated land area (14 ha), the largest ( $p$ $<0.001$ ) sizes of small ruminants, cattle herds and poultry flocks. They also possessed the largest ( $\mathrm{p}<0.001)$ agricultural equipment value (1967190 FCFA). They were significantly more educated and more involved in farmers' association (64\%) than those from the NI and PI groups. They were more present in the rural $(59 \%)$ than in the urban $(32 \%)$ areas.

\section{Determinants of integration}

The likelihood of a farm to practice a given crop-livestock integration type significantly $(\mathrm{p}<0.05)$ depends on its participation in a farmers' association, the value of its equipment and the number of cattle raised (Table 4).

The probability for a group with no integration (NI) to adopt total integration practices is 1 time lower when equipment value increases of one unit, 0.898 times greater when the cattle herd size increases of one head and 33 times lower in the absence of membership in farmers' association. So, the probability that a farmer with no integration practices accepts to adopt total integration ones increases with the cattle herd size, the membership in a farmers' association and the lowest of the equipment value. The probability for a group of farmers with partial integration to adopt total integration practices is 0.891 times greater when the cattle herd size increases of one head and 0.945 times greater when the agricultural experience increases of one year. In other words, the probability that a farmer with partial integration practices decide to upgrade to total integration ones increases with the cattle herd size and the agricultural experience in years. In fact, agricultural experience of farmers' influence on integration adoption is significant $(\mathrm{p}=0.029)$ in the final model. The high significance of the model $(\mathrm{p}<0.001)$ on the one side and the non-significance of Hosmer and Lemeshow test $(\mathrm{p}=0.620)$ combined with adequate predictions (Table 5: $69.2 \%$ of total success, $18.2 \%$ of group who reported to use total integration practices, $72 \%$ of those who have opted for partial integration practices and $77.9 \%$ for those who did not practice any form of integration) of individual farmers in their respective crop-livestock integration groups confirmed the validity of the regression model. 
Table 1: Description of variables used to characterize small farmers and their integration practices in three agroecological zones of Benin.

\begin{tabular}{|c|c|c|}
\hline & Farm characteristics & Integration practices \\
\hline \multicolumn{3}{|c|}{ Nominal variables } \\
\hline AREA & Agroecological area $(I I I, V I, V I I I)$ & Cereal residues utilization (yes, no) \\
\hline SEX & Gender of the head of household (Male, Female) & Legume residues utilization (yes, no) \\
\hline EDUC & $\begin{array}{l}\text { Formal education level of the head of household (none, } \\
\text { primary, secondary, university) }\end{array}$ & $\begin{array}{l}\text { Roots/tubers residues utilization (yes, } \\
\text { no) }\end{array}$ \\
\hline LITERACY & The head of household is literate (yes, no) & $\begin{array}{l}\text { Vegetables residues utilization (yes, } \\
\text { no) }\end{array}$ \\
\hline ASSOMEMB & $\begin{array}{l}\text { The head of household is member of an association in the } \\
\text { village (yes, no) }\end{array}$ & Manure utilization (yes, no) \\
\hline CREDIT & Access to credit by the head of household (yes, no) & $\begin{array}{c}\text { Small ruminants dejections utilization } \\
(\text { yes }, \text { no })\end{array}$ \\
\hline FERTILEVEL & Fertility level of soil in head of household field (low, good) & Poultry dejections utilization (yes, no) \\
\hline \multicolumn{3}{|l|}{ Metric variables } \\
\hline AGE & Age of household head (in years) & \\
\hline HHSIZE & Number of persons living in the household $(n)$ & \\
\hline AGRIEXP & Number of years of experience in agriculture & \\
\hline FIELSIZE & Total field size (in ha) & \\
\hline N_SRUM & Total number of small ruminant reared & \\
\hline N_POULTRY & Total number of poultry reared & \\
\hline N_CATTLE & Total number of cattle reared & \\
\hline EQUIVAL & $\begin{array}{l}\text { Total agricultural and household equipment (trait oxen, } \\
\text { tractor, household goods) value }\end{array}$ & \\
\hline
\end{tabular}


B. I. KOURA et al. / Int. J. Biol. Chem. Sci. 9(5): 2272-2283, 2015

Table 2: Variations of integration levels according to farms nominal characteristics.

\begin{tabular}{|c|c|c|c|c|c|}
\hline & NI $(n=86)$ & PI $(n=132)$ & TI $(n=22)$ & $\mathrm{Chi}^{2}$ & Sig. \\
\hline Variables & & Percent $(\%)$ & & & \\
\hline AREA & & & & 109.650 & $* * *$ \\
\hline Rural & 29 & 32 & 59 & & \\
\hline Periurban & 71 & 13 & 9 & & \\
\hline Urban & 0 & 55 & 32 & & \\
\hline SEX & & & & 2.832 & NS \\
\hline Male & 99 & 95 & 100 & & \\
\hline Female & 1 & 5 & 0 & & \\
\hline EDUC & & & & 16.790 & $* *$ \\
\hline None & 52 & 37 & 27 & & \\
\hline Primary & 43 & 42 & 41 & & \\
\hline Secondary & 5 & 18 & 27 & & \\
\hline University & 0 & 3 & 5 & & \\
\hline LITERACY & & & & 0.332 & NS \\
\hline No & 87 & 89 & 86 & & \\
\hline Yes & 13 & 11 & 14 & & \\
\hline ASSOMEMB & & & & 47.766 & $* * *$ \\
\hline No & 88 & 44 & 36 & & \\
\hline Yes & 12 & 56 & 64 & & \\
\hline CREDIT & & & & 5.835 & NS \\
\hline No & 92 & 86 & 73 & & \\
\hline Yes & 8 & 14 & 27 & & \\
\hline FERTILEVEL & & & & 5.278 & NS \\
\hline Weak & 42 & 48 & 23 & & \\
\hline Good & 58 & 52 & 77 & & \\
\hline
\end{tabular}


B. I. KOURA et al. / Int. J. Biol. Chem. Sci. 9(5): 2272-2283, 2015

Table 3: Variations of integration levels according to farms metric characteristics.

\begin{tabular}{|c|c|c|c|c|}
\hline Variables & NI $(n=86)$ & $P I(n=132)$ & TI $(n=22)$ & $P$ \\
\hline AGE & & & & NS \\
\hline Mean & 39.4 & 38.1 & 42.9 & \\
\hline $\mathrm{SD}$ & 12.0 & 10.9 & 15.5 & \\
\hline HHSIZE & & & & * \\
\hline Mean & $8.12^{\mathrm{ac}}$ & $7.32^{\mathrm{a}}$ & $9.71^{\mathrm{b}}$ & \\
\hline SD & 3.76 & 5.76 & 6.49 & \\
\hline AGRIEXP & & & & $* *$ \\
\hline Mean & $17.3^{\mathrm{ac}}$ & $15.6^{\mathrm{a}}$ & $21.8^{\mathrm{b}}$ & \\
\hline SD & 10.9 & 9.17 & 9.25 & \\
\hline FIELSIZE & & & & $* * *$ \\
\hline Mean & $8.08^{\mathrm{ac}}$ & $7.21^{\mathrm{a}}$ & $13.6^{\mathrm{b}}$ & \\
\hline SD & 8.69 & 13.0 & 15.5 & \\
\hline N_SRUM & & & & $* * *$ \\
\hline Mean & $5.24^{\mathrm{ac}}$ & $6.09^{\mathrm{a}}$ & $12.5^{\mathrm{b}}$ & \\
\hline SD & 5.65 & 11.9 & 13.0 & \\
\hline N_POULTRY & & & & $* * *$ \\
\hline Mean & $23.0^{\mathrm{ac}}$ & $15.4^{\mathrm{a}}$ & $83.3^{\mathrm{b}}$ & \\
\hline $\mathrm{SD}$ & 51.4 & 40.2 & 226 & \\
\hline N_CATTLE & & & & $* * *$ \\
\hline Mean & $1.61^{\mathrm{ac}}$ & $1.28^{\mathrm{a}}$ & $12.0^{\mathrm{b}}$ & \\
\hline SD & 5.56 & 2.99 & 24.7 & \\
\hline EQUIVAL & & & & $* * *$ \\
\hline Mean & $355063^{a}$ & $743273^{\mathrm{b}}$ & $1967190^{c}$ & \\
\hline SD & 319886 & 1603066 & 2620783 & \\
\hline
\end{tabular}


Table 4: Multinomial logistic regression Likelihood Ratio Tests.

\begin{tabular}{|c|c|c|c|c|}
\hline \multirow[t]{2}{*}{ Effect } & \multirow{2}{*}{$\begin{array}{c}\text { Model Fitting Criteria } \\
\text {-2 Log Likelihood of Reduced Model }\end{array}$} & \multicolumn{3}{|c|}{ Likelihood Ratio Tests } \\
\hline & & Chi-Square & df & Sig. \\
\hline Intercept & $334.058^{\mathrm{a}}$ & 0.000 & 0 & 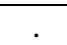 \\
\hline EQUIPVAL & 355.254 & 21.196 & 2 & $* * *$ \\
\hline N_CAT & 342.453 & 8.395 & 2 & $*$ \\
\hline AGRIEXP & 338.682 & 4.624 & 2 & NS \\
\hline ASSOMEMB & 398.564 & 64.506 & 2 & $* * *$ \\
\hline
\end{tabular}

a. This reduced model is equivalent to the final model because omitting the effect does not increase the degrees of freedom. NS=not significant; $*=\mathrm{p}<0.05 ; * *=\mathrm{p}<0.01 ; * * *=\mathrm{p}<0.001$.

Table 5: Multinomial logistic regression classification table.

\begin{tabular}{lcccc}
\hline Observed & \multicolumn{4}{c}{ Predicted } \\
\cline { 2 - 5 } & No integration & $\begin{array}{c}\text { Partial } \\
\text { integration }\end{array}$ & Total integration & Percent Correct \\
\hline No integration & 67 & 18 & 1 & $77.9 \%$ \\
Partial & 35 & 95 & 2 & $72.0 \%$ \\
integration & 2 & 16 & 4 & $18.2 \%$ \\
Total integration & $43.3 \%$ & $53.8 \%$ & $2.9 \%$ & $69.2 \%$ \\
Overall & & & & \\
Percentage & & & & \\
\hline
\end{tabular}

\section{DISCUSSION}

\section{Crop livestock integration and farmers' socioeconomic characteristics}

Farmers who do not adopt any form of integrated crop-livestock practices show some socioeconomic characteristics less interesting whereas those who really integrate are better ranked. In general, from no integration to total integration farmers' endowment with respect to animal herd sizes, membership in farmers' association, equipment value and level of education increase. Although the level of education seems not to be significant in determining crop-livestock integration, the higher educational status of group of farmers with higher levels of integration militates in favor of the education as a motivating factor of integration practices (Adesina and Chianu, 2002; Somda et al., 2002). Also, is it not the group of farmers with total integration (TI) the most involved in agriculture? Is it not integration a way out of high risks in agriculture? Then, farmers with total integration (TI) could justify their practices as risks reduction strategy with ecological benefits (Vall et al., 2012). It is the rationale why these integration practices predominate in rural areas where crop residues and manure are more available.

\section{Factors affecting the adoption of crop- livestock integration}

As for all innovative practices, many factors influence the adoption of integration. Cattle herd size, membership in farmers' association, agricultural experience and equipment value determine farmers' trend to integration. Among these factors, only the influence of cattle keeping on crop-livestock integration has been reported in literature, by Smith et al. (1997). Adesina and Chianu (2002) on the one side and Nkamleu and Manyong (2005) on the other side corroborate those four factors as determinants agricultural innovations adoption by small farmers. Other authors identify factors like age of farmers, education level, literacy, gender, household size, access to credit and farmers' perception (Adesina and Chianu, 2002; Somda et al., 2002). Most of the latter factors are recently identified as determinants for adoptingadaptive strategies to climate change 
(Hassan and Nhemachena, 2008; Deressa et al., 2009). If those characteristics are not significant in determining for crop-livestock integration by small farmers, it is because of the diversity of origins of surveyed farmers (rural, periurban and urban farmers) and so forth the heterogeneity in farmers' characteristics, while works above address typical rural farmers.

There should be equivalence between equipment value found as statistically significant for no integration and cattle size found as statistically significant for the partial integration. In the same vein, there should be a relationship between agricultural experience and ages of farmers (Table 3 ). In fact, farmers who totally integrate are older and more skilled than those who partially integrate. Experienced farmers are likely to know more and understand risks and adequate adaptive strategies to soil fertility management and crop residues feeding practices. Adesina and Chianu (2002) recognize it as determinants for adopting an alley farming technology in Nigeria, while Maddison (2006) mentioned this importance of experience in farmers' adaptation to climate change. Indeed, like for educated farmers, experience improves awareness of potential benefits and willingness to adopt an innovative practice. Thus, experienced farmers are expected to have more knowledge and information about agronomic practices that they can use in response (Maddison, 2006). Farmers' experience is improved with their membership in association. Nkamleu and Manyong (2005) acknowledged the importance of this factor and what such a contact can achieve in the adoption of agro-forestry practices in Cameroon. This factor, while facilitating experiences sharing among farmers, promotes their contact with local stakeholders in agricultural sector and thus allows them to gain practical knowledge. Those innovative practices often aim at reducing farmers' vulnerability to major risks like decreased soil fertility and forage scarcity. Indeed, young farmers can benefit of experience of oldest ones on their innovative practices. This can also facilitate a better understanding of croplivestock integration practices. Latter in the past, the influence of cattle keeping on cropping and livestock rearing integration has been acknowledged (McIntire et al., 1992; Smith et al., 1997). While quite old, findings of these authors confirmed our results. According to Smith et al. (1997), insertion of livestock in farming systems is one such a motor of a real and a viable integration of cropping and rearing. The authors explained that crop-livestock integration facilitates the use of draught animals and very much improve quality and opportunity for cropping practices. Scarcity of forage during the dry season matches with the availability of crop residues and then facilitates their use as foodstuffs, while manure is used in turn for fertilization (Franke et al., 2008).On the other hand, the negative correlation between the adoption of integration practices and equipment value reveals that those practices are adopted by small holders with low equipment. This result corroborates Vall et al. (2012) findings stating that crop and livestock integration is a good issue for small holders facing the ongoing agricultural crisis.

\section{Conclusion}

Our investigation revealed that the three integration levels identified differed significantly according to socioeconomic characteristics of the farmer such as his membership in farmers' association, his educational level, the weight of his agricultural experience, his farm equipment and the size of his animal herds. For improving integration adoption in subSaharan Africa, small-farmers can be motivated to join a farmers' association in order to benefit of experience of their pairs and be awarded of innovative practices. On the other, they could be made award of keeping cattle, for expecting a real integration of both agriculture and livestock productions. One perspective issue for this study is to investigate the potential advantage of endogenous crop-livestock systems for both productions and on livelihood of the farmers.

\section{COMPETING INTERESTS}

The authors declare that they have no competing interests. 


\section{AUTHORS' CONTRIBUTIONS}

BIK and DH contributed to all the steps leading to this manuscript (study preparation, data collection, data analysis, manuscript design and preparation, manuscript correction); BVK contributed to data collection, data analysis and manuscript writing; HLD and GPM contributed to data analysis, manuscript design and correction; $\mathrm{FH}, \mathrm{PH}$ and $\mathrm{MH}$ contributed to the study preparation, manuscript design and correction.

\section{REFERENCES}

Adesina AA, Chianu J. 2002. Determinants of farmers' adoption and adaptation of alley farming technology in Nigeria. Agroforest. Syst., 55(2): 99112.DOI: 10.1023/A:1020556132073.

Akoegninou A, van der Burg WJ, van der Maesen LJG, Adjakidje V, Essou JP, Sinsin B, Yedomonhan H. 2006. Analytical Flora of Benin ( $1^{\text {st }}$ edn). Backhuys Publishers: Cotonou, Benin \&Wageningen.

Babbie ER. 2009. The Practice of Social Research $\left(12^{\text {th }}\right.$ edn). Wadsworth Publishing: Bedmont, California.

Coulibaly D. 2008. Socio-technical change in the dairy production systems and marketing of milk in periurban area of Sikasso, Mali. PhD thesis, Agro Paris Tech, France, p. 399.

Dercon S. 2002. Income risk, coping strategies and safety nets. World Bank Res. Obs., 17: 141166.DOI: 10.1093/wbro/17.2.141.

Deressa TT, Hassan RM, Ringler C, Alemu T, Yesuf M. 2009. Determinants of farmers' choice of adaptation methods to climate change in the Nile Basin of Ethiopia. Sci. Tech., 19(2): 248255.DOI:10.1016/j.gloenvcha.2009.01. 002.

Dugue P, Dongmo AL. 2004. Animal traction and, cropping and livestock association in the west and central Africa savannah. From a technicist model to a process of integration. Elev. Med. Vet. Pays Trop., 57(3-4): 157-165.
FAO. 2009. World state of food and agriculture: http://www.fao.org/ catalog/inter-e.htm

Franke AC, Laberge G, Oyewole BD, Schulz S. 2008. A comparison between legume technologies and fallow, and their effects on maize and soil traits, in two distinct environments of the West African savannah. Nutr. Cycl. Agroecosys., $\quad \mathbf{8 2}$ : $\quad 117-$ 135.DOI:10.1007/s10705-008-9174-2.

Franke AC, Berkhout ED, Iwarfor ENO, Nziguyeba G, Dercon G, Vandeplas I, Diels J. 2010. Does crop-livestock integration lead to improved crop production in the savanna of West Africa? Expl. Agric., 46(4): 439-455. DOI: $\quad$ http://dx.doi.org/10.1017/ S0014479710000347.

Hassan R, Nhemachena C. 2008. Determinants of African farmers' strategies for adapting to climate change: multinomial choice analysis. African J. Agric. Resource Econ., 2(1): 83-104.

INSAE. 2012. Satistiques/ Statistiques économiques/ Production agricole. http://www.insae-bj.org/productionagricole.html. (Consulted on December 12, 2014).

Koura BI, Dossa LH, Kassa B, Houinato M. 2015. Adaptation of peri-urban cattle production system to environmental changes: herders feeding strategies in southern Benin. Agroecol. Sust. Food, 39(1): $\quad$ 83-98. DOI:10.1080/21683565.2014.953662.

Maddison D. 2006. The Perception of and Adaptation to Climate Change in Africa. Centre for Environmental Economics and Policy in Africa (CEEPA), University of Pretoria. Discussion Paper No. 10.

McIntire JD, Bourzat, Pingali P. 1992. Crop Livestock Interaction in Sub-Saharan Africa. Regional and Sectoral Studies Series. The World Bank, Washington, DC.

Mohammed Saleem MA. 1997. Comments made at the ILRL/FAO/IDRC/INFORUM E- 
Conference: 'Balancing Livestock, the Environment and Human Needs', April 1997.

Nkamleu GB, Manyong VM. 2005. Factors affecting the adoption of agroforestry practices by farmers in Cameroon. Small-scale Forest Economics Management and Policy, 4(2): 135148.DOI: 10.1007/s11842-005-0009-6.

Rufino MC. 2008. Quantifying the contribution of crop-livestock integration to African farming. $\mathrm{PhD}$ Thesis, Wageningen University, The Netherlands. P. 294.

Smith JW, Naazie A, Larbi A, Agyemang K,Tarawali S. 1997. Integrated croplivestock production systems in subSaharan Africa: an option or an imperative. Outlook Agric., 26: 237246.

Somda J, Nianogo AJ, Nassa S, Sanou S. 2002. Soil fertility management and socio-economic factors in croplivestock systems in Burkina Faso: a case study of composting technology. Ecol. Econ., 43(2-3): 175-183. DOI:10.1016/S0921-8009(02)00208-2.
SPSS Inc. 2010. PASW (Predictive Analytics Software) 17.0.SPSS Inc., Chicago, IL, USA.

Thornton PK, Herrero M. 2001. Integrated crop-livestock simulation models for scenario analysis and impact assessment. Agr. Syst., 70: 581-602. DOI:10.1016/S0308-521X(01)00060-9.

Vall E, Dugue P, Blanchard M. 2006. The weaving of cropping and livestock relationship over cotton thread, 19902005.Cah. Agric., 15(1): 72-79.

Vall E, Andrieu N, Chia E, Nacro HB. 2012. Partnership, modeling, experiment: what lessons for the design of innovation and ecological intensification. Proc. ASAP seminar 2011, 13p.

Volkoff B. 1976-1978. Pedological Reconnaissance Soil Map at 1:200 000 of the People's Republic of Benin. ORSTOM. Paris.

Wolmer W. 1997. Crop-Livestock Integration: The Dynamics of Intensification in Contrasting Agroecological Zones: A Review. IDS Working Paper 63, Brighton: IDS. 